\title{
Ferrocifens and Ferrocifenols as New Potential Weapons against Breast Cancer
}

\author{
Anh Nguyen, Anne Vessières, Elizabeth A. Hillard, Siden Top, Pascal Pigeon, and Gérard Jaouen* \\ Dedicated to Professor Wolfgang Beck in honor of his pioneering work in bioorganometallic chemistry
}

\begin{abstract}
Depending on the presence or absence of the estrogen receptor in the cells, breast cancer today is often treated by endocrine therapy (tamoxifen) or chemotherapy, respectively. We present now a new paradigm for breast cancer treatment, taking advantage of concepts in bioorganometallic chemistry. In this way, we have synthesized molecules containing an organometallic moiety (ferrocene), and a biovector (hydroxytamoxifen), yielding compounds which display a new therapeutic spectrum consisting of antiestrogenicity and cytotoxicity. A structure-activity relationship study has shown that a ferrocene group, linked to a para-phenol group by a conjugated spacer, is a necessary motif for strong cytotoxic effects to be observed.
\end{abstract}

Keywords: Bioorganometallic chemistry · Breast cancer · Ferrocene · Iron · SERMs

\section{Introduction}

Breast cancer is the leading cause of cancer death among women in Europe, ${ }^{[1]}$ while in the US it is surpassed only by lung cancer. ${ }^{[2]}$ Nearly one in three cancers diagnosed in US women is for breast cancer, according to the American Cancer Society. [3] Each year, about 42,000 new cases are expected to occur in France, 270,000 cases in the US, and more than 1 million worldwide. Approximately 11,000 women are expected to die from this disease in France this year, 40,000 in the US, and ten times more globally. In terms of incidence rate, breast cancer touches one woman in eight in the Western World.

Most women with breast cancer will undergo some type of surgical excision, often combined with other treatments such as hormone therapy, radiation therapy, chemotherapy, ${ }^{[3]}$ and very recently monoclonal antibody therapy with Herceptin ${ }^{\circledR}$ for patients overexpressing a specific protein (HER2). ${ }^{4,5]}$ Breast tumors are tradition-

${ }^{\star}$ Correspondence: Prof. G. Jaouen Laboratoire de Chimie Organométallique Ecole Nationale Supérieure de Chimie de Paris UMR C.N.R.S. 7576

11, rue Pierre et Marie Curie

75231 Paris 05, France

Tel.: +33143269555

Fax: +33143260061

E-Mail: gerard-jaouen@enscp.fr ally classified according to their estrogen receptor status: hormone-dependent tumors (estrogen receptor positive; ER+), and hormone-independent tumors (estrogen receptor negative; ER-). This designation comes from the fact that hormone-dependent cancer cells, whose proliferation is induced by the hormone estradiol, exhibit a high accumulation of a specific intracellular receptor protein: the alpha form of the estrogen receptor $(\mathrm{ER} \alpha)$. For these patients an adjuvant treatment with anti-estrogens ${ }^{[6,7]}$ or more recently with aromatase inhibitors ${ }^{[8,9]}$ is currently used.

In the case of ER- breast tumors, antiestrogens are not effective and chemotherapy is then generally prescribed to eradicate cancer cells that could not be removed by excision or that may have already invaded other parts of the body. It has been established that a combination of drugs is more effective than just one drug alone for breast cancer treatment. Thus, the first-line chemotherapies are usually a combination of three of the following drugs: 5-fluorouracil, doxorubicin (adriamycin ${ }^{\circledR}$ ), cyclophosphamide, methotrexate, paclitaxel $\left(\operatorname{taxol}^{\circledR}\right)$, and epirubicin (Fig. 1). [10]

The molecules used in chemotherapy are highly cytotoxic, and can reduce mortality by up to $20 \%$. ${ }^{[11]}$ They affect cell division, and hence are very effective on fastdividing cells such as tumors. But, this also means that fast-dividing cells such as those

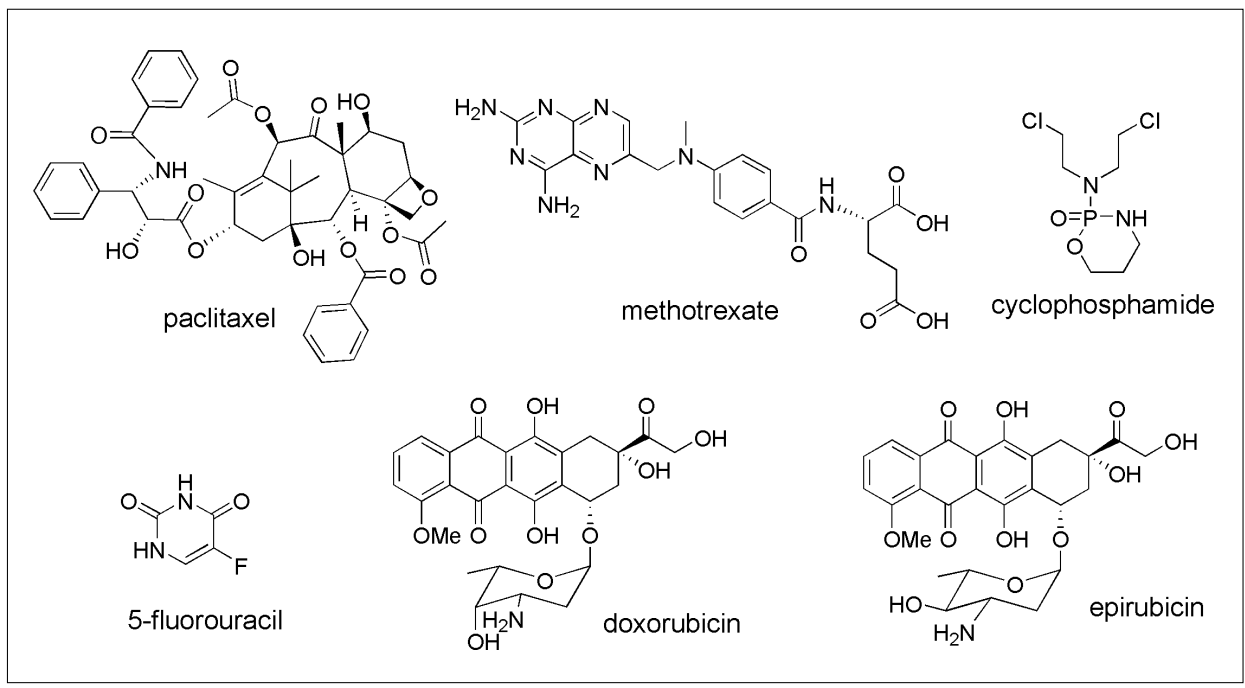

Fig. 1. Molecules used in the treatment of hormone independent breast cancers 
involved in hair growth, the replacement of the intestinal epithelium, or the production of white blood cells are also affected. The physical drawbacks include nausea, fatigue, nerve damage, anemia, hair loss, and a weaker resistance to infections.

However, the finding of hormone responsiveness in two-thirds of breast cancer cases $(\mathrm{ER}+)$ triggered the development of antiestrogens, molecules which could compete with estradiol at its specific receptor and inhibit its proliferative action. This hormone therapy offers the advantages of being less aggressive and producing fewer side-effects than undiscriminating radioand chemotherapy for patients having hormone-dependent breast cancer. ${ }^{[12-15]}$

\section{Ligand-Receptor Relationship and Anti-hormone Therapy}

In the hormone-induced pathway, when the natural ligand estradiol $\left(\mathrm{E}_{2}\right)$ binds to its intranuclear receptor, it induces a typical conformational change in the protein structure, involving Helix 12.[12,13,16] This enables the recruitment of co-activators and the dimerization of ER. The homo/heterodimer then binds to small palindromic ERE (Estradiol Response Element) sequences of DNA. The interaction allows the recruitment of transcription factors from the general transcription machinery around Polymerase II, and thus initiates gene transcription and specific protein synthesis leading finally to cell proliferation (Fig. 2) ${ }^{[17]}$ Therefore, in ER+ tumors, the increased concentration of estrogen receptors is associated with cell multiplication.

Transcription can also be regulated by estrogens through another pathway, the indirect AP-1 pathway. In this mechanism, the activated estrogen receptor associates with co-activator proteins (in particular the dimer jun/fos), and not directly with DNA. These co-activators then bind to another region of DNA (the AP-1 site), and enhance transcription activity. ${ }^{[18,19]}$

Since the binding of estradiol to its receptor promotes breast cancer cell proliferation in ER+ tumors, many molecules have been synthesized to counteract its action. The first nonsteroidal antiestrogen was etamoxytriphetol, MER-25 (Fig. 3). [20] Unfortunately, its very low affinity for ER, low potency and serious central nervous system sideeffects hindered further development. ${ }^{[12-14]}$ It was quickly discovered that the key feature for the recognition of a ligand by the ER is the presence of a phenol group analogous to phenol A of estradiol, ${ }^{[21-23]}$ which is lacking in MER-25. Consequently, the structures of the synthetic antiestrogens are mainly derived from estradiol itself or from diphenyl ethylene synthetic estrogens such as diethylstilbestrol (Fig. 3).

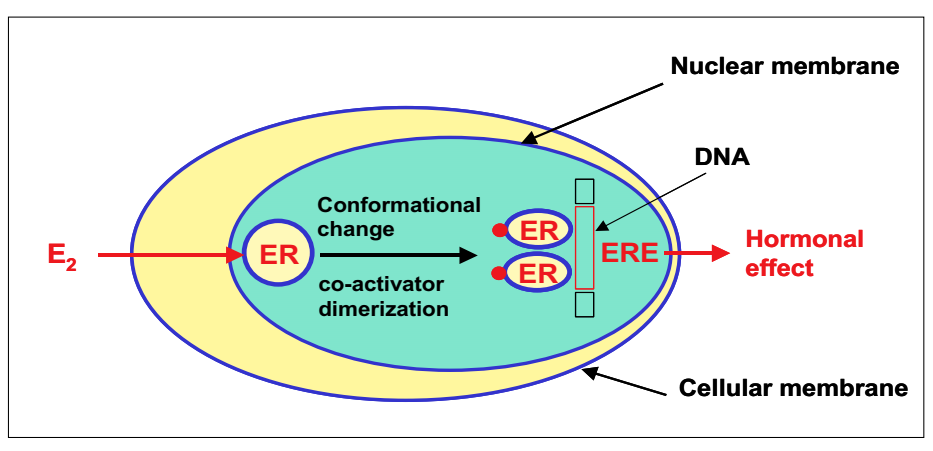

Fig. 2. Schematic mechanism of action of estradiol in estrogen receptor positive cells

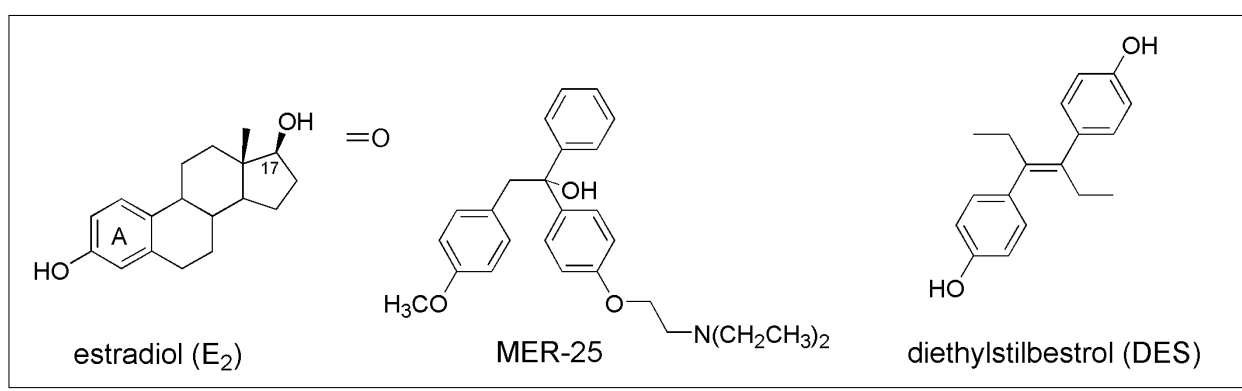

Fig. 3. Natural (E2) and synthetic (MER-25 and DES) ligands of the estrogen receptor

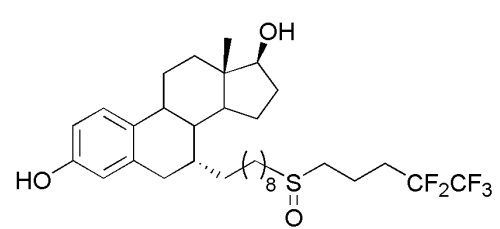

Fulvestrant

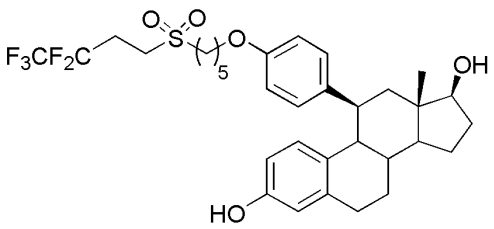

RU 58668

Fig. 4. Examples of some pure antiestrogens

\section{Pure Antiestrogens}

To be a pure antiestrogen, the molecule must have a unique mechanism of action, independent of the cellular context. It would prevent the formation of a transcription complex at target genes, and/or enhance the ability of the ER complex to be destroyed, once bound to the receptor. The steroidal pure antiestrogen ICI 182,780 (fulvestrant, Fig. 4) first prepared and tested in the $90 \mathrm{~s}^{[24,25]}$ is the most effective in this series. Since 2000, it has been approved by the FDA as a second-line drug for the treatment of advanced breast cancer and is marketed under the brand name Faslodex ${ }^{\circledR}{ }^{\circledR}[13]$ Its success stimulated the search for other potential agents, such as RU 58668 (Fig. 4).[26] These pure antiestrogens block ER nuclear localization by inducing a protein synthesis-dependent clustering of ER in the cytoplasm. It has been proposed that the long hydrophobic side-chain of these antiestrogens significantly disrupts the ER protein structure, resulting in cytoplasmic paralysis and rapid destruction of the ER.

Apart from the increased risks of osteoporosis and coronary heart disease, the other main problems associated with the pure antiestrogens described so far are poor bioavailability and the route of administration. Steroidal molecules are highly hydrophobic, thus excluding oral administration. Patients have to pay monthly visits to the hospital in order to receive a fulvestrant slow-release depot injection. This mode of administration is generally considered highly inconvenient.

In order to improve the bioavailability of RU 58 668, Renoir and co-workers have designed an efficient drug delivery nanosystem for the antiestrogen. The long-circulating, stealth drug carriers are polymeric nanoparticles, which are loaded with the bioactive compound whose ability to arrest tumor growth has been strongly enhanced in vitro and in vivo, thanks to this encapsulation. ${ }^{[27,28]}$

\section{Selective Estrogen Receptor Modulators (SERMs)}

In the search for better estradiol antagonists, researchers noticed that some antiestrogens showed partial estrogen agonist activity, depending on the target tissue. 
These Selective Estrogen Receptor Modulators (SERMs) display an unusual tissueselective pharmacology: agonists in some tissues (bone, liver, cardiovascular system), antagonists in others (brain, breast), and mixed agonists/antagonists in the uterus. The hope is that they would act as antiestrogens in the breast and uterus where they would limit estrogenic proliferative effects, but that they would retain estrogenic benefits for bones and the heart. The huge libraries of SERMs include families of triphenylethylenes (TPE), benzothiophenes, and indoles. ${ }^{[12-15]}$

Most of the SERMs share the stilbenetype common structural pattern of two aryl groups separated by two atoms, (Fig. 3). The most popular and widely prescribed SERM for hormone-dependent breast cancer, tamoxifen (Novaldex ${ }^{\circledR}$ ), possesses an additional third phenyl group and thus belongs to the triphenyethylene family. Its active metabolite, hydroxytamoxifen $(\mathrm{OH}-$ Tam), acts as an antagonist of estradiol in ER+ breast tumors (Fig. 5). ${ }^{[7]}$

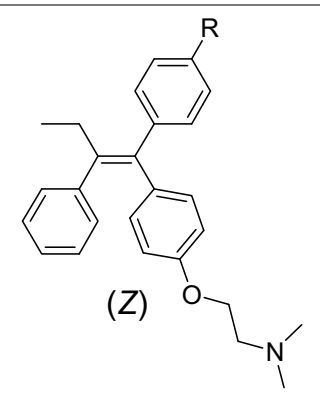

$\mathrm{R}=\mathrm{H}:$ tamoxifen

$\mathrm{R}=\mathrm{OH}$ : hydroxytamoxifen $(\mathrm{OH}-\mathrm{Tam})$

Fig. 5. Tamoxifen and its active metabolite, (Z)-hydroxytamoxifen

The dimethylaminoethoxy side chain interaction with Asp 351 of the binding site of the ER is held responsible for the observed antiestrogenic effect of hydroxytamoxifen. ${ }^{[6,16,29]}$ This side-chain induces Helix 12 to undergo a conformational change different from the one observed with estradiol. This prevents the recruitment of co-activators, and favors the binding of co-repressors instead. However, depending on the nature of the gene promoter to which hydroxytamoxifen binds and the cellular context (e.g. the major type of ER ( $\alpha$ or $\beta$ ) present in the tissue and the co-activator/co-repressor ratio in the cell), this SERM can also act as an agonist. Thus, just like estradiol, OH-Tam can induce beneficial effects such as maintaining bone density, but unfortunately it also slightly enhances endometrial tumor growth.

The tamoxifen analogue GW-5638 (Fig. 6), discovered by Willson and coworkers at Glaxo Wellcome in 1994, presents the interesting feature of changing the usual tertiary amino antiestrogenic side-chain of

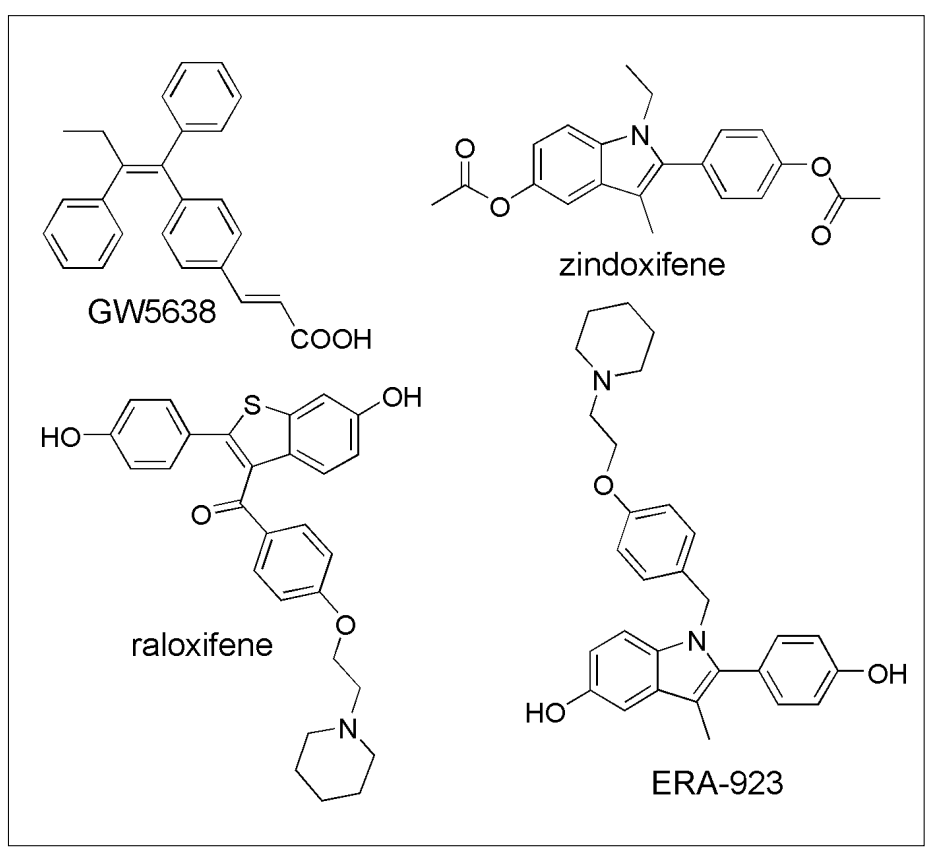

Fig. 6. Some SERMs

tamoxifen to an allylcarboxylic group. ${ }^{[30,31]}$ Molecular modeling disclosed that the carboxylic side-chain could repel Asp351 of $\mathrm{ER}$, and therefore produces a subtle, but significant change in protein folding. The change in coregulator binding classifies this molecule as a new SERM, which could even reduce ER levels and has no uterotrophic activity.

Raloxifene is a benzothiophene SERM (Fig. 6). Like tamoxifen, it acts as an estrogen antagonist in breast tissue through competitive binding to ER. Formally known as LY 156,758 or keoxifen, it was first developed in the early 1980s as a candidate for the treatment of breast cancer, along with tamoxifen. ${ }^{[32]}$ However, it performed poorly against tamoxifen in laboratory models, and in tamoxifen-resistant patients. No further development followed, until its ability to maintain bone density in postmenopausal women was recognized, resulting in the approval under the new name of raloxifene for the treatment and prevention of osteoporosis (Evista $\left.{ }^{\circledR}\right) .{ }^{[33,34]}$

Early studies of 2-hydroxyphenylindoles by von Angerer and coworkers ${ }^{[35,36]}$ demonstrated antitumor activity for this class of compounds. Although zindoxifen (Fig. 6) looked promising, it proved to be an inactive antitumor agent in phase II clinical trials. However, deacetylation and substitution of the indole nitrogen with long aminoalkyl side-chains gave birth to potent antiestrogens, such as ERA-923 (Fig. 6) which is currently in phase II clinical trials for the treatment of hormone-dependent breast cancer. ${ }^{[37]}$

Unfortunately, the successful treatment of breast cancer by hydroxytamoxifen is also overshadowed by the fact that a third of hormone-dependent breast tumors do not respond to the endocrine therapy, and some of those that initially respond to the antihormonal treatment acquire resistance in the long term. ${ }^{[19,38]}$ To those cases of intrinsic and acquired resistance, the class of insensitive ER-negative tumor cells have to be added in order to point out the limitation of hydroxytamoxifen. These cases highlight the dire need for new active molecules with broader therapeutic scopes.

\section{Development of Metal-based Bioactive Molecules}

Metals are often considered to be toxic for living systems. However, any toxicity of metal ions depends on their actual concentration in the organism, because "dosis sola facit venenum", as Paracelsus already stated during the Renaissance. In fact many metalbased proteins such as nitrogenase and the class of cytochrome oxidase enzymes are required in important biological processes. Furthermore, some metal-containing molecules are necessary for life, such as cobaltcontaining Vitamin $\mathrm{B}_{12}$, where early signs of its deficiency include anemia and macrocytosis. Vitamin $B_{12}$, its coenzyme $B_{12}$, and methylcobalamin were the first natural compounds with a carbon-metal bond to be described. Thanks to their role in biology, use of metals in medicine could hold great promise. ${ }^{[39]}$

The first successful bioactive organometallic compound was the famous antisyphilis drug Salvarsan, discovered by Paul Ehrlich, who introduced at the same time the notion of receptors and chemotherapy ('magic bullets'). By the end of the twentieth century, another major breakthrough renewed interest in biomedical metal-based chemistry. It was the discovery of the coordination metal complex cisplatin by 
Rosenberg. ${ }^{[40-42]}$ This inorganic complex (Fig. 7) showed highly toxic effects, especially on cancer cells. This therapeutic advance came together with a better theoretical understanding and control of new types of metal-ligand bonds, which enabled the discovery of a broad range of new complexes. ${ }^{[43]}$ This is particularly important as cisplatin possesses serious limitations such as a narrow therapeutic window and drug resistance problems. ${ }^{[44]}$ It is worthwhile to note that cisplatin is not used for treatment of breast cancer, although it is widely prescribed for other types of cancer such as testes carcinoma. Indeed, its $\mathrm{IC}_{50}$ value for MDA-MB-231 cells (hormone-independent breast cancer cells) is quite high, about 12 $\mu \mathrm{M}$, which is not a very potent cytotoxic activity. ${ }^{[45]}$

Currently, the two most widely used cisplatin analogues are carboplatin (Paraplatin $^{\circledR}$ ) and oxaliplatin (Eloxatin ${ }^{\circledR}$ ), (Fig. 7). ${ }^{[46]}$ The first drug is similar to cisplatin, in terms of activity, but has a lower systemic toxicity. The second one is a thirdgeneration drug effective against some cisplatin-resistant cancers, such as metastatic colorectal cancer when associated with 5-fluorouracil.[47]

Many researchers have proposed a variety of complexes in which steroidal or nonsteroidal ligands were attached to platinum, in order to add selectivity to the transport of $\mathrm{Pt}$, to overcome the problem of resistance, and to smoothen undesirable side-effects observed in cisplatin therapy. Moreover, if the bioligand is an antiestrogen, this single drug could combine antiestrogenic and cytotoxic properties, thus bringing forth a new therapeutic spectrum.

\section{Platinum Complex SERMs}

Due to their historical primacy, platinum complexes have been the first metal moieties to be coupled to estradiol, ${ }^{[48-52]}$ and later, to hydroxytamoxifen (Fig. 8). ${ }^{53,54]}$ Although 1 showed antiproliferative effects on breast cancer cells at high concentrations (around $5 \mu \mathrm{M}$ ), the effects are similar to those observed for the corresponding platinum complex alone, without the bioligand vector. On the other hand, 4 does recognize the estrogen receptor $(\mathrm{RBA}=6.4 \%)$, but its antiproliferative effects on MCF-7 breast cancer cells seem to be mostly anti-hormonal, the Pt fragment showing only slight cytotoxicity on these cells. ${ }^{[54]}$ A surprising biological behavior was observed for cationic platinum estradiol complexes 2 and 3. Compound 2 did show a cytostatic effect on the MCF-7 breast cancer cell line at $5 \mu \mathrm{M}$, but direct hormonal activity of this complex seems unlikely. ${ }^{[55]}$ An unprecedented higher binding affinity for the ER was noticed for

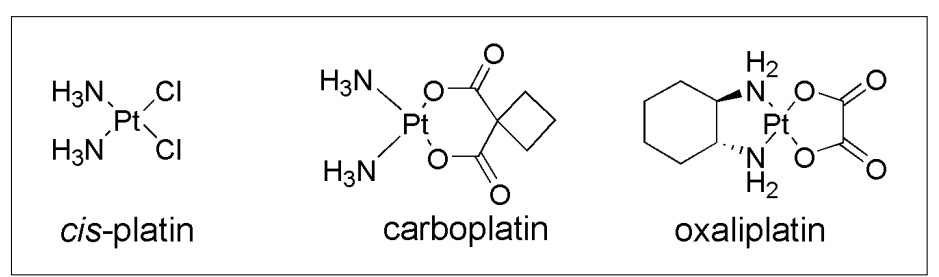

Fig. 7. Inorganic platinum complexes currently in clinical use

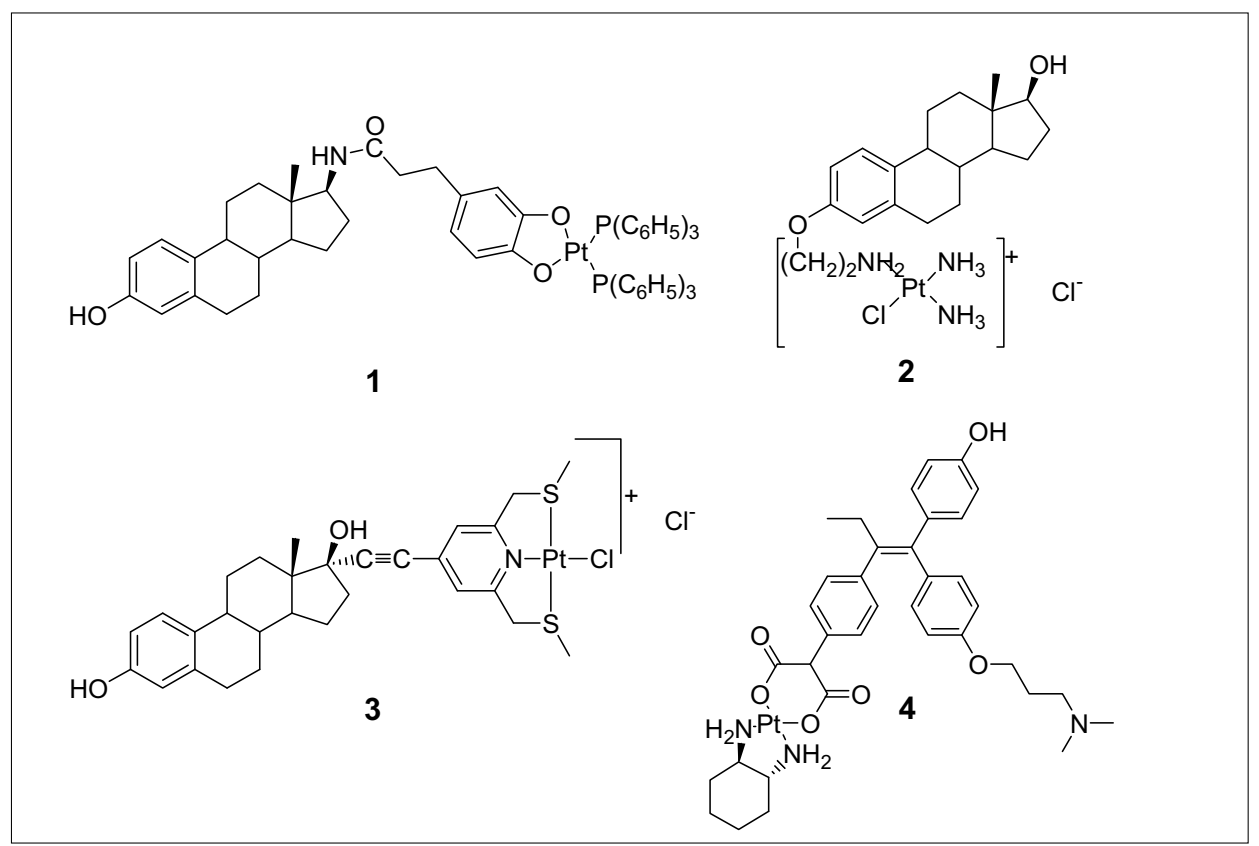

Fig. 8. Examples of platinum complexes of estradiol and tamoxifen

the cationic complex 3 than for its metalfree ligand. ${ }^{[56]}$ But more importantly, despite its cationic character, the compound was able to cross the cellular membrane. It seems that the hydrophobicity and size of the complex is more important than the charge.

It should be mentioned that 1-4 are coordination compounds. The coordinating character of the metal-ligand bonds makes these compounds susceptible to solvolysis. While the hydrolysis of the chloride ligands is necessary for the activity of cisplatin, in the case of biovector-platinum combinations, loss of the biovector may explain their lower (or even lost) biological potency in physiological media. Thus, other metal systems are sought.

\section{Bioactive Organometallic Compounds}

Organometallic chemistry refers to the chemistry of metal complexes bearing at least one metal-carbon bond. Organometallic compounds, having metal-ligand bonds with a strong covalent character, are often more stable than inorganic metal coordination complexes. ${ }^{[57]}$ For instance, ferrocene has been thoroughly studied thanks to its robustness. More generally, metallocenes are small, rigid, and lipophilic molecules which can easily cross cellular membranes. Therefore, the idea to use targeted organometallic bioligands for medical purposes naturally sprang to the mind of some researchers about 30 years ago. The sandwich structure formed by two cyclopentadienyl rings in metallocenes resembles that of an aromatic substituent, both in terms of geometry and aromatic properties. The relative stability of metallocenes in biological media is another argument to encourage their application as tracers or vectorized bioactive compounds.

This approach was used by Edwards and coworkers in the 1970s to produce ferrocenyl antibiotics against penicillin resistant bacteria (5 and 6 in Fig. 9). ${ }^{[58-60]}$ In vivo toxicology studies on ferrocene derivatives disclosed low levels of toxicity, despite liverrelated problems. Developed in the former USSR for the treatment of iron-deficiency anemia, a sodium salt of $o$-carboxybenzoyl ferrocene $\mathbf{7}$ is well tolerated for oral administration, and can also be prescribed for gum diseases. ${ }^{[61]}$ The idea to modify the structure of organic bioactive compounds was taken up by Brocard and coworkers to produce ferroquine in 1997 8. $^{[62]}$ This compound is a 
ferrocenyl analogue of chloroquine, a wellknown antimalarial drug (Fig. 9). Thanks to the additional ferrocenyl moiety, ferroquine is not only active against chloroquine-sensitive bacteria, but also against chloroquineresistant strains. The active molecule is now in phase II clinical development by SanofiAventis. ${ }^{[63]}$

\section{Ferrocene-containing Anticancer Compounds}

Although the anticancer potential of ferrocene derivatives was first studied in the late 1970s, this field of investigation truly started after 1984, when Köpf-Meyer, Köpf, and Neuse disclosed the anti-tumor activity of ferricenium salts. ${ }^{[64]}$ Soon thereafter, Neuse proposed that ferrocenyl derivatives could be oxidized in the cell via normal metabolic processes, so that both ferricenium and ferrocene derivatives could yield an anti-proliferative effect. ${ }^{[65]}$ DNA damage caused by free radicals generated by the Fenton pathway has been suggested for their mechanism of action. ${ }^{[66-68]}$ Ferrocene could be oxidized to the ferricenium radical cation, which can catalytically form $\mathrm{O}_{2}{ }^{-}$and hydroxyl radical in the presence of water and $\mathrm{O}_{2}$. It has been shown that these radicals influence the apoptosis of cells and can damage the DNA.

\section{Ferrocifens}

In 1996, a little earlier than the advent of ferroquine, Jaouen and coworkers coupled ferrocene to the biovector hydroxytamoxifen. ${ }^{[69,70]}$ The resulting 'hydroxyferrocifens' (differentiated by the length of the dimethyl amino chain, $\mathrm{n}=2-5,8$ ) were designed to combine the antiestrogenic properties of tamoxifen with the potentially cytotoxic effect of ferrocene to possibly obtain new therapeutic advantages.[71-73] To create the hydroxyferrocifens, a phenyl group of 4-hydroxytamoxifen is replaced by ferrocene. Since ferrocene is intrinsically aromatic, its presence in lieu of the phenyl group should not cause serious deterioration of recognition by the estrogen receptor. The most efficient synthetic path to substituted butenes relies on the key step of a McMurry cross-coupling between a ferrocenyl ketone and the 4,4'-dihydroxybenzophenone (Scheme 1). The $Z$ and $E$ isomers were separated at the very end by fractional crystallization $(n=3)$ and plate chromatography $(n=4)$.

Since the isomerization between the $E$ and $Z$ isomers of the hydroxyferrocifens is very rapid in protic solvents, biological tests in aqueous media have been performed with mixtures of isomers. However, for the relative binding affinity (RBA) assessment with $\mathrm{ER} \alpha$ and $\beta$, the general observation that the $Z$ isomer of triphenylethylene-type molecules was better recognized than its $E$-counterpart was verified. The compounds were dissolved in DMSO for these experiments, because the isomerization is very slow or even non-existent in non-protic solvents. Although displaying less affinity for the estrogen receptor than hydroxytamoxifen, the hydroxyferrocifens were nonetheless satisfactorily recognised by the ER $(n=2-5)$. The lower values were probably due to the steric effect of the ferrocenyl group which is slightly bigger than the phenyl moiety. Also for steric reasons, the longer the amino side-chain, the lower the receptor affinity.

The antiproliferative activity of the ferrocenyl derivatives was evaluated on MCF-7 cells, which are hormone-dependent breast cancer cells having an important concentration of ER $\alpha$, and on MDAMB-231 cells, which are classified as hormone-independent breast cancer cells because they are devoid of ER $\alpha$. It was found that on MCF-7 cells, the effects of the hydroxyferrocifens are quite similar to that of hydroxytamoxifen, slightly more potent at a concentration of $0.1 \mu \mathrm{M}$, and definitely superior at $1 \mu \mathrm{M}$. But the remarkable behavior of these compounds is with the MDA-MB-231 cells, with a very low $\mathrm{IC}_{50}$ value $(0.5 \mu \mathrm{M})$ as shown in the Table. While hydroxytamoxifen was completely inactive on the hormone-independent cells, the hydroxyferrocifens displayed a strong antiproliferative effect on the cells. Consequently, two kinds of behavior could be put forward: one which is similar to the antiestrogenic role of hydroxytamoxifen on the estrogen receptor, and one which involves the in situ activation of the ferrocenyl function. It is worthwhile to note that ferrocene alone is not active against the proliferation of cancer cells.

Molecular modeling of $\mathbf{9 b}$, the most potent compound of this series, has confirmed that the molecule can be accommodated by the binding site of ER $\alpha$ in its antagonist configuration. The interaction

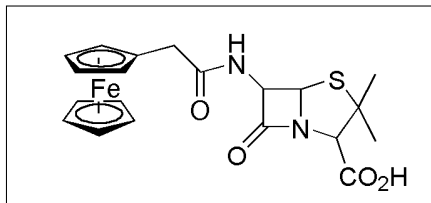

5

ferrocenyl penicillin

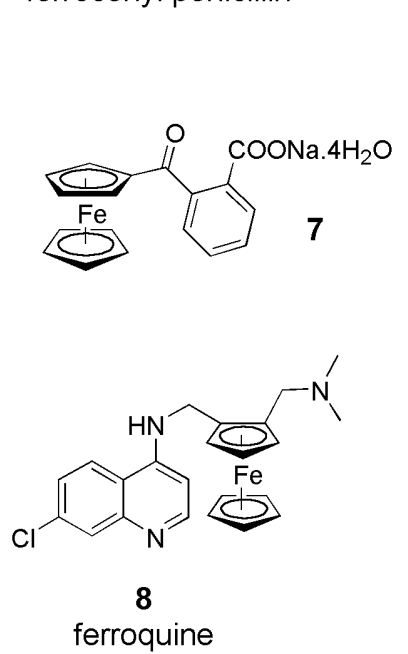

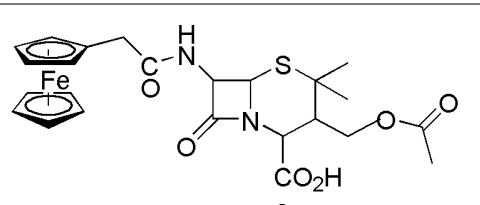

6

ferrocenyl cephalosporin

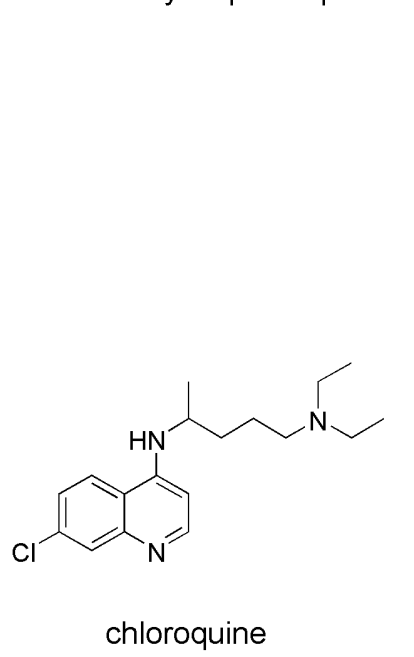

Fig. 9. Some bioactive ferrocenyl compounds

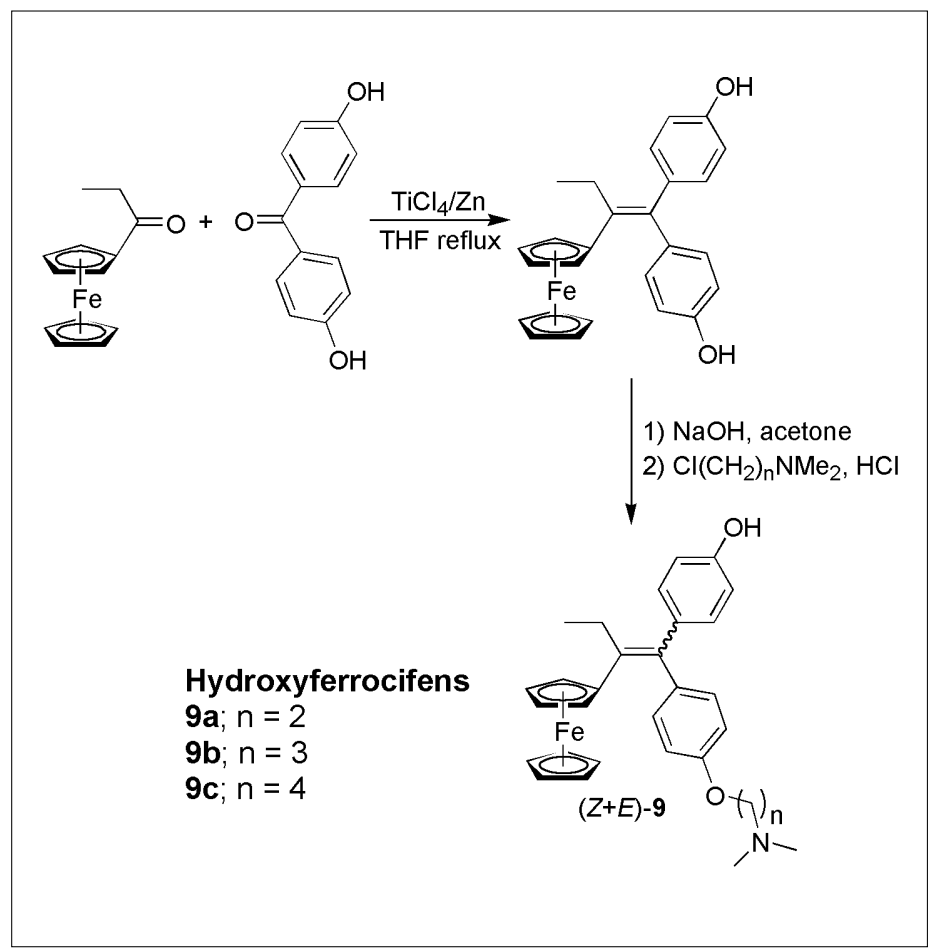

Scheme 1. Synthetic pathway to hydroxyferrocifens 
Table. $\mathrm{IC}_{50}$ values of some of the ferrocenyl complexes on hormone-independent breast cancer cells MDA-MB-231

\begin{tabular}{ll} 
Compound & $I_{50}$ values $(\mu \mathrm{M})$ \\
\hline $\mathbf{9 b}$ & $0.5[74]$ \\
$\mathbf{1 0}$ & $>25^{[75]}$ \\
$\mathbf{1 1}$ & $13.4[75]$ \\
& $0.6[76]$ \\
$\mathbf{1 2}$ & $0.44[78]$ \\
$\mathbf{1 3}$ & $6^{a}$ \\
$\mathbf{1 4 a}$ & $2.8[77]$ \\
$\mathbf{1 4 b}$ & $4.1[77]$ \\
$\mathbf{1 4 c}$ & $3.5[77]$ \\
$\mathbf{1 6}$ & $2.8[78]$ \\
$\mathbf{1 7}$ & $3.5[78]$ \\
$\mathbf{1 8}$ & $1.03[78]$ \\
$\mathbf{1 9}$ & $1.13[78]$ \\
$\mathbf{2 0}$ & $2.7^{[78]}$ \\
a unpublished & results
\end{tabular}

between Asp 351 and the nitrogen of the amino side-chain, important for the antiproliferative activity of hydroxytamoxifen, provided the correct positioning of the organometallic molecule. This interaction supports the observation that the antiestrogenic effect is comparable to that of hydroxytamoxifen.

However, the origin of the cytotoxic effect is not at all obvious. In order to determine the structures and functional groups necessary for a ferrocene containing molecule to give rise to a cytotoxic effect, we have performed a series of anti-cancer structure-activity relationship studies. The stepwise modification of one aspect of the hydroxyferrocifen molecule has led to a several analogous compounds shown in Scheme 2.

\section{Ferrocenyl Estradiol Derivatives}

The above experiments with the hydroxyferrocifens showed that the vectorization of ferrocene with a SERM can yield a molecule which exhibits both antiestrogenic and cytotoxic properties. While the anti-estrogenic effect is clearly due to the binding of the compound in the ER, the mechanism of cytotoxicity is not clear. Because ferrocenium has been shown to damage DNA via ROS production, ${ }^{[66]}$ one might imagine that merely transporting the ferrocene entity into the nucleus would be sufficient to give rise to cytotoxic effects. In order to investigate this possibility, ferrocene was grafted onto the $17 \alpha$-position of the estradiol skeleton to produce the two hybrid compounds $\mathbf{1 0}$ and $\mathbf{1 1}$ (Table). ${ }^{[75]}$ At a concentration of $1 \mu \mathrm{M}$, these complexes have a strong estrogenic effect on the hormone dependent MCF-7 cells and no effect on the hormone independent MDA-MB-231 cells. The behavior of the two complexes diverges when higher concentrations are used. The ethynyl ferrocenyl estradiol becomes toxic at high concentrations, with a modest $\mathrm{IC}_{50}$ value of $13.4 \mu \mathrm{M}$, while the ferrocenyl estradiol molecule is still not toxic at a concentration of $25 \mu \mathrm{M}$, the limit of its solubility (Table). Thus, it is clear that the mere presence of a ferrocenyl entity in the interior of the nucleus is not enough to cause an antiproliferative effect. Instead, the structure of the diphenylethylene skeleton must also play some role in the hormone-independent cytotoxicity of the hydroxyferrocifens.

\section{Anticancer Structure-Activity Studies of Ferrocifenols}

\section{Dimethylamino Side Chain}

The role of the dimethylamino side chain, which is thought to be responsible for the antiproliferative effect of hydroxytamoxifen, was appraised by examining the proliferative/antiproliferative effects of the diphenolic hydroxytamoxifen analog 12 (Scheme 2), where the chain has been replaced by a second hydroxyl group. Its regio-isomer 13, obtained by exchanging the phenyl and ferrocenyl substituents, was also studied (Scheme 2). ${ }^{[76]}$

On MCF-7 cells, 12 gave rise to a strong anti-proliferative effect, while the simple position change in the ferrocenyl substituent gives 13, with completely different behavior, in fact with practically no effect at all against the ER+ cell line. It is important to point out that the antiproliferative effect found for $\mathbf{1 2}$ can only be attributed to a cytotoxic effect, as this compound, lacking the side chain, would be expected to interact with the ER like an estrogen. This receptor-independent cytotoxicity is also clearly shown on the MDA-MB-231 cells. Again, the diphenol $\mathbf{1 2}$ is strongly cytotoxic at $1 \mu \mathrm{M}$, with an $\mathrm{IC}_{50}$ value of $0.44 \mu \mathrm{M}$, similar to that of the hydroxyferrocifen with a three-carbon atom chain, while its regio-isomer is only slightly cytotoxic with an $\mathrm{IC}_{50}$ value of $6 \mu \mathrm{M}$ (Table). These results clearly show the importance of the position of the ferrocenyl group for the cytotoxicity of the complexes. On the other hand, the dimethylamino side chain, although necessary for antiestrogenicity, is apparently not important for cytotoxicity.

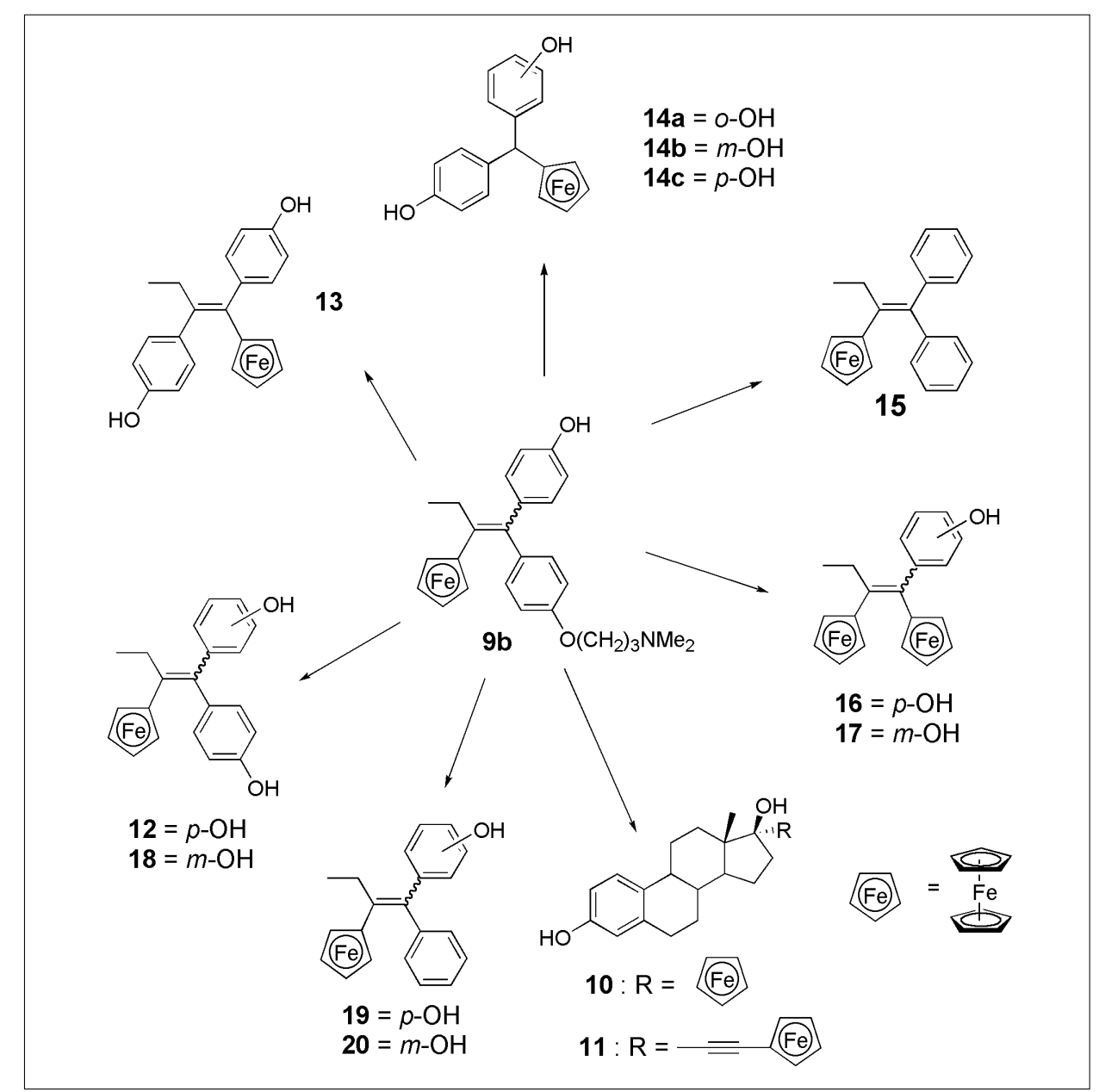

Scheme 2. Ferrocenyl compounds used in anticancer structure-relationship studies 


\section{Conjugation}

To establish the role of the conjugated system in the cytotoxicity of the hydroxyferrocifen $9 \mathrm{~b}$ and diphenol 12, ferrocenyl diphenols linked by a $\mathrm{sp}^{3}$ carbon instead of an ethylene group (14a-c, Scheme 2) were synthesized and tested against the ER+ and ER- cell lines. ${ }^{[77]}$ For each of these three complexes, one phenolic hydroxyl group remains in the para position, while the position of the second phenol varies between the ortho, meta, and para positions. On ER+ cells, at a concentration of $1 \mu \mathrm{M}$, these complexes have a fairly clear estrogenic effect; although weaker than that of estradiol, this was expected based on their chemical structure, which lacks the amino side chain. On ER-cells, still at the same concentration of $1 \mu \mathrm{M}$, a slight antiproliferative effect is observed; substantially less important than that found for compound 12. These complexes become toxic at higher concentrations, as shown by their $\mathrm{IC}_{50}$ values, respectively 2.8 , 4.1 , and $3.5 \mu \mathrm{M}$, approximately five times higher than the $\mathrm{IC}_{50}$ value found for $\mathbf{1 2}$ (Table). Thus it appears, all other elements being equal, the compound possessing a $\pi$-system considerably outperforms its tetrahedral analog.

\section{Presence and Position of the Phenol Group}

The diphenyl analog of 12, 2-ferrocenyl1,1-diphenyl-but-1-ene $\mathbf{1 5}$ was studied in order to evaluate the importance of the presence of the phenol functionality. This compound shows a clear proliferative effect on the MCF-7 ER+ cell line, and is not cytotoxic at a concentration of $1 \mu \mathrm{M}$ against the MDA-MB-231 cells line. ${ }^{[78]}$ Thus the phenol group does indeed contribute to the cytotoxicity of the hydroxyferrocifens.

The relevance of position of the phenol functionality was studied via a series of para- and meta-substituted mono- and di-ferrocenyl phenols (2-ferrocenyl-1-(4- hydroxyphenyl)-1-phenyl-but-1-ene 16, 2 ferrocenyl-1-(3-hydroxyphenyl)-1-phenyl -but-1-ene 17, 2-ferrocenyl-1-(3-hydroxyphenyl)-1-(4-hydroxyphenyl)-but-1-ene 18, 1,2-di-ferrocenyl-1-(4-hydroxyphenyl) -but-1-ene 19, and 1,2-di-ferrocenyl-1-(3hydroxyphenyl)-but-1-ene 20). The cytotoxic effects of the phenolic complexes are indeed related to the positioning of the hydroxyl group (para- superior to meta-), with $\mathrm{IC}_{50}$ values against the MDA-MB231 cell line ranging from 1.03-3.5 $\mu \mathrm{M}$ (Table). On the hormone-dependent breast cancer cell line MCF7, the observed effect seems to be the result of two components, one cytotoxic (antiproliferative) and one estrogenic (proliferative)

\section{Summary}

Through the study of a variety of hydroxyferrocifen analogs, it was quickly recognized that the molecules of this series which possess a particular structural pattern including a conjugated system linking a ferrocenyl and phenol group show the strongest cytotoxic effects. This study has also provided us with a group of ferrocenyl complexes at our disposal with a range of $\mathrm{IC}_{50}$ values between 0.44 and $13 \mu \mathrm{M}$. One of the most cytotoxic complexes is the hydroxyferrocifen $9 \mathrm{~b}$, with an $\mathrm{IC}_{50}$ value of $0.5 \mu \mathrm{M}$. It is interesting to note that the corresponding organic complex, hydroxytamoxifen, has a very high $\mathrm{IC}_{50}$ value of $30 \mu \mathrm{M}$ on the MDAMB-231 cell line ${ }^{[79]}$ and that ferrocene alone has no toxic effect whatsoever. ${ }^{[73]}$ However by combining these two entities, the hydroxytamoxifen and ferrocene, we have created a new molecule which is strongly cytotoxic; with an $\mathrm{IC}_{50}$ value 60 times smaller than that of hydroxytamoxifen.

Finally, the role played by the iron seems to be essential as the ruthenocenyl and cyclopentadienyl tricarbonyl rhenium derivatives of hydroxytamoxifen have not shown cytotoxic properties. ${ }^{[80-83]}$ The ruthenocenyl, cyclopentadienyl tricarbonyl rhenium and cymantrenyl derivatives of the diphenol $\mathbf{1 2}$ were also non-cytotoxic. ${ }^{[84]}$

\section{Mechanism of Cytotoxicity}

Thus, the structural design involving '(ferrocene)-(conjugated spacer)-(paraphenol)' seems to be crucial to the mechanism of cytotoxicity. Electrochemical experiments have suggested that those compounds possessing this structural motif can undergo two one-electron oxidations to yield a quinone methide-type structure. ${ }^{[85]}$ Although it is well-known that a variety of phenolic compounds, including hydroxytamoxifen, ${ }^{[86]}$ can be oxidized to the corresponding quinonoid, the presence of a ferrocene group seems to act as an oxidation catalyst, as shown in Scheme 3. In the electrochemical experiments, the ferrocenium moiety appears to act as an intramolecular oxidizing agent by accepting an electron from the organic skeleton, although it is not currently clear if the electron transfer occurs after the first or second oxidation. Whatever the exact details of the mechanism, the resulting electrophilic quinone methide species can then form adducts with biological nucleophiles, such as glutathione.

The '(ferrocene)-(conjugated spacer) -(para-phenol)' is absolutely required to obtain the quinone methide type structure via the proposed mechanism. For example, if the hydroxyl group is moved from the para- to the meta-position, quinone methide formation is blocked, resulting in ratios of $\mathrm{IC}_{50}$ values of 17 versus 16 and 18 versus $\mathbf{1 2}$ of 2.4 and 2.3, respectively (Table). Similarly, when ferrocene is directly linked to the phenol group by an $\mathrm{sp}^{3}$ carbon, the resulting molecules $\mathbf{1 4 a}-\mathbf{c}$ were five to seven times less efficient in inhibiting the proliferation of MDA-MB-231 cells. Another study of a compound lacking this $\pi$-system,
Scheme 3. A proposed mechanism for transforming 16 into a quinone methide species

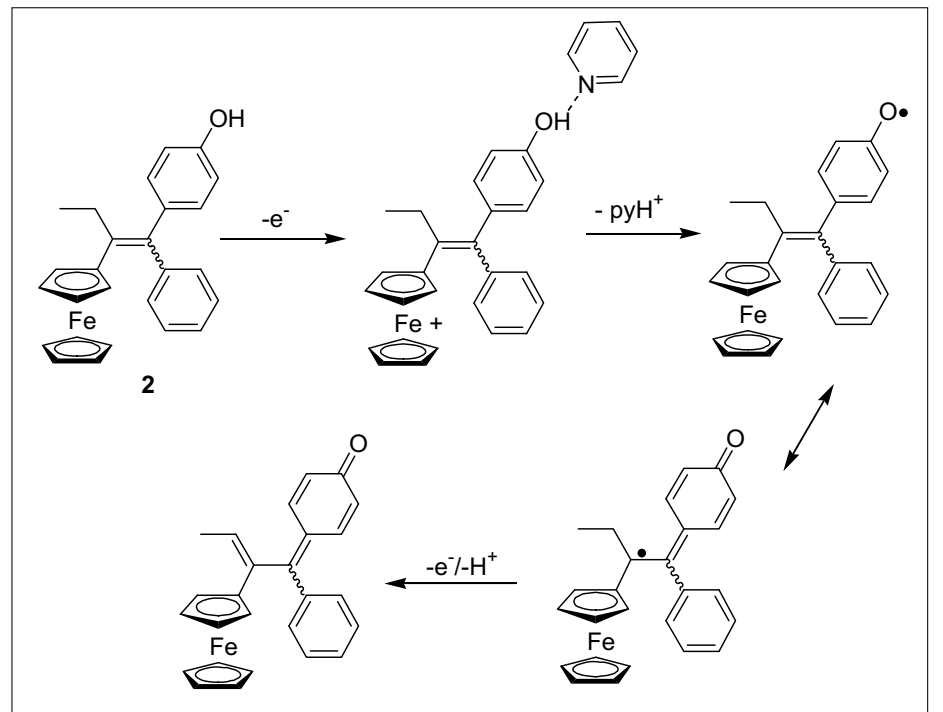

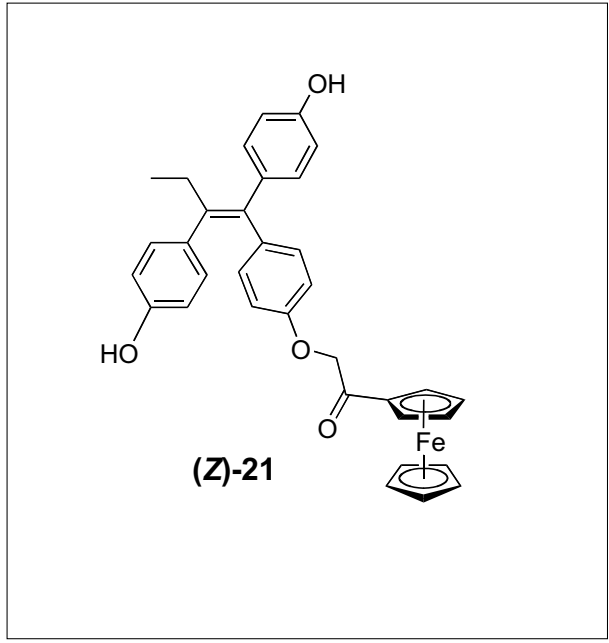

Fig. 10. (Z)-21 


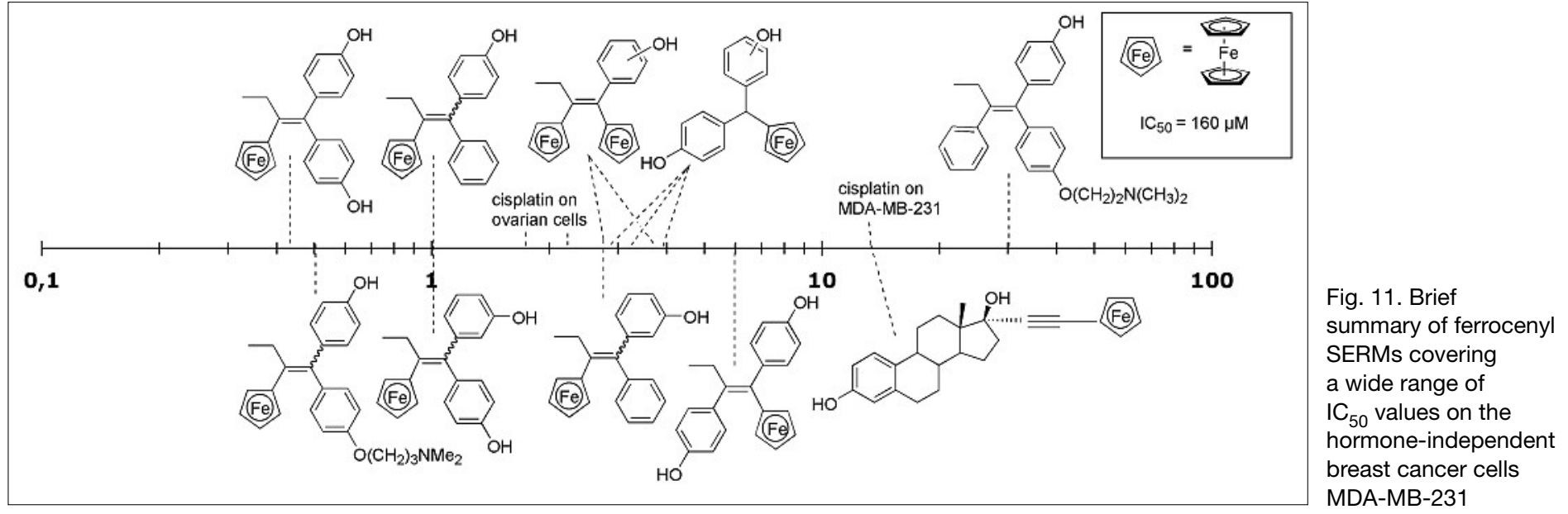

by placing this time the ferrocenyl group on the key antiestrogenic amino side-chain of hydroxytamoxifen (21 in Fig. 10), also resulted in a decreased inhibitory activity, but still undoubtedly cytotoxic. ${ }^{[87,88]}$ Modification of this key amino side-chain by another chemical function has been rarely attempted, the only other main functional modification was with carboxylic acid[ ${ }^{[30,89]}$ and hydroxyl groups. ${ }^{[90,91]}$

\section{Conclusion}

Despite huge progress since the midtwentieth century, current breast cancer treatment would still benefit by becoming milder, safer and more successful. This review has briefly outlined an original approach to new potential bioactive molecules for the treatment of breast cancer. This bioorganometallic concept could offer a plausible alternative to chemotherapy (with its drastic side-effects), and tamoxifen (with its problems of resistance). Indeed, the combination of the antiestrogenic quality of the biovector hydroxytamoxifen with a cytotoxic ferrocenyl moiety conferred an enhanced antiproliferative activity to the SERM tamoxifen, and gave rise to broader therapeutic possibilities, especially in the tamoxifen-resistant cases. By combining two non-active species (hydroxytamoxifen and ferrocene) on the hormone-independent breast cancer cells, we have created a series of new molecules, covering a wide range of $\mathrm{IC}_{50}$ values (Fig. 11).

It should be emphasized that the simple presence of a ferrocenyl group is not sufficient to yield cytotoxic compounds. For example, a proliferative activity was found for the ferrocenyl estradiol, where the ferrocene group is attached to the $17 \beta$ position on the estradiol structure. Both the position and the structural pattern in which ferrocene is inserted are important, as shown by the structure-activity relationship studies. For these compounds, the motif '(ferrocene)-(conjugated spacer)(para-phenol)' seems to be crucial for the strong cytotoxic effects. A change in the position of either the hydroxy group or the ferrocene resulted in a weakened cytotoxic effect. A mechanism befitting those observations confers to this conjugated $\pi$-system the essential role of electron tunnel. Ferrocene seems to play the role of an intramolecular oxidation catalyst for the phenol, in order to facilitate the production of cytotoxic species. If this tunnel is disrupted, the $\mathrm{C}=\mathrm{C}$ being replaced by an $\mathrm{sp}^{3}$ carbon for example, then a significant decrease in cytotoxic activity is observed.

This article illustrates the rich possibilities that the emerging field of bioorganometallic chemistry can offer to oncology research, by bringing together a metallic entity and bioactive organic molecules. The most active organometallic compounds could be potential drug candidates for the treatment of breast cancer. However, their in vivo application may be impeded by problems of bioavailability. Indeed, especially for phenols, chemical compounds are liable to be degraded or opsonized and removed from blood circulation by macrophages of the reticuloendothelial system. In order to increase the circulation time in the bloodstream and to enhance the probability of the molecule to extravasate in tumor tissues, some of these active ferrocenyl molecules had been successfully protected inside nanoparticles, which seemed to delay their release in the biological medium. ${ }^{[87]}$

Received: August 20, 2007

[1] http://www.encr.com.fr

[2] A. Jemal, R. Siegel, E. Ward, T. Murray, J. $\mathrm{Xu}, \mathrm{M}$. J. Thun, CA Cancer J. Clin. 2007, $57,43$.

[3] American Cancer Society, http://cancer. org/docroot/home/index.asp

[4] G. Ismael, D. D. Rosa, E. de Azambuja, S. Braga, M. Piccart-Gebhart, Hematol. Oncol. Clin. North. Am. 2007, 21, 239.

[5] C. A. Hudis, N. Engl. J. Med. 2007, 357, 39.

[6] V. C. Jordan, J. M. G. Schafer, A. S. Levenson, H. Liu, K. M. Pease, L. A. Simons,
J. W. Zapf, Advances in Cancer Research 2001, 61, 6619 .

[7] V. C. Jordan, 'Tamoxifen for the treatment and prevention of breast cancer', PRR, Inc., New York, 1999.

[8] J. M. Dixon, Expert. Opin. Pharmacother. 2004, 5, 307.

[9] E. P. Winer, C. Hudis, H. J. Burstein, A. C. Wolff, K. I. Pritchard, J. N. Ingle, R. T. Chlebowski, R. Gelber, S. B. Edge, J. Gralow, M. A. Cobleigh, E. P. Mamounas, L. J. Goldstein, T. J. Whelan, T. J. Powles, J. Bryant, C. Perkins, J. Perotti, S. Braun, A. S. Langer, G. P. Browman, M. R. Somerfield, J. Clin. Oncol. 2005, 23, 619.

[10] Early breast cancer trialist's collaborative group (EBCTCG), Lancet 2005, 365, 1687.

[11] G. N. Hortobagyi, A. U. Buzdar, CA Cancer J. Clin. 1995, 45, 199.

[12] V. C. Jordan, J. Med. Chem. 2003, 46, 883.

[13] V. C. Jordan, J. Med. Chem. 2003, 46, 1081.

[14] R. A. Magarian, L. B. Overacre, S. Singh, K. L. Meyer, Curr. Med. Chem. 1994, 1, 61.

[15] M. J. Meegan, D. G. Lloyd, Curr. Med. Chem. 2003, 10, 181.

[16] A. K. Shiau, D. Barstad, P. M. Loria, L. Cheng, P. J. Kushner, D. A. Agard, G. L. Greene, Cell 1998, 95, 927.

[17] C. K. Osborne, H. Zhao, S. A. W. Fuqua, J. Clin. Oncol. 2000, 18, 3172.

[18] P. Webb, P. Nguyen, C. Valentine, G. N. Lopez, G. R. Kwok, E. McInerney, B. S. Katzenellenbogen, E. Enmark, J.-A. Gustafsson, S. Nilsson, P. J. Kushner, Mol. Endocrinol. 1999, 1672.

[19] C. K. Osborne, N. Eng. J. Med. 1998, 339, 1609.

[20] E. R. Clark, V. C. Jordan, Br. J. Pharmacol. 1976, 57, 487.

[21] F. S. Zeelen, E. W. Bergink, in 'Cytotoxic estrogens in hormone receptive tumors', Eds. J. Raus, H. Martens, G. Leclercq, Academic Press, London, 1980, pp. 39.

[22] J. P. Raynaud, T. Ojasoo, M. M. Bouton, E. Bignon, M. Pons, A. Castres de Paulet, in 'Estrogens in the Environment', Ed. McLachlan, Elsevier, Amsterdam, 1985. 
[23] G. M. Anstead, K. E. Carlson, J. A. Katzenellenbogen, Steroids 1997, 62, 268.

[24] A. E. Wakeling, M. Dukes, J. Bowler, Cancer Res. 1991, 51, 3867.

[25] A. E. Wakeling, J. Bowler, J. Steroid Biochem. Mol. Biol. 1992, 43, 173.

[26] P. Van de Velde, F. Nique, F. Bouchoux, J. Bremaud, M. C. Hameau, D. Lucas, C. Moratille, S. Viet, D. Philibert, G. Teutsch, $J$. Steroid Biochem. Mol. Biol. 1994, 48, 187.

[27] T. Ameller, V. Marsaud, P. Legrand, R. Gref, J. M. Renoir, Int. J. Cancer 2003, 106, 446.

[28] S. Maillard, T. Ameller, J. Gauduchon, A. Gougelet, F. Gouilleux, P. Legrand, V. Marsaud, E. Fattal, B. Sola, J.-M. Renoir, J. Steroid Biochem. Mol. Biol. 2005, 94, 111.

[29] J. I. MacGregor, V. C. Jordan, Pharmacol. Rev. 1998, 50, 151.

[30] T. M. Willson, J. D. Norris, B. L. Wagner, I. Asplin, P. Baer, H. R. Brown, S. A. Jones, B. Henke, H. Sauls, S. Wolfe, D. C. Morris, D. P. McDonnell, Endocrinology 1997, 138, 3901.

[31] Y.-L. Wu, X. Yang, Z. Ren, D. P. McDonnell, J. D. Norris, T. M. Willson, G. L. Greene, Molecular Cell 2005, 18, 413

[32] J. A. Clemens, D. R. Bennett, L. J. Black, C. D. Jones, Life Sci. 1983, 32, 2869.

[33] V. C. Jordan, J. Cell Biochem. Suppl. 1995, 22, 51.

[34] S. L. Willhite, S. R. Goebel, J. A. Scoggin, Ann. Pharmacother. 1998, 32, 834.

[35] E. Von Angerer, J. Prekajac, J. Med. Chem. 1983, 26, 113

[36] E. Von Angerer, N. Knebel, M. Kager, B. Ganss, J. Med. Chem. 1990, 33, 2635.

[37] C. P. Miller, M. D. Collini, B. D. Tran, H. A. Harris, Y. P. Kharode, J. T. Marzolf, R. A. Moran, R. A. Henderson, R. H. W. Bender, R. J. Unwalla, L. M. Greenberger, J. P. Yardley, M. A. Abou-Gharbia, C. R. Lyttle, B. S. Komm, J. Med. Chem. 2001, 44, 1654.

[38] J. S. Lewis, V. C. Jordan, Mutation Research/Fundamental and Molecular Mechanisms of Mutagenesis 2005, 591, 247.

[39] G. Jaouen, W. Beck, M. J. McGlinchey, in 'Bioorganometallics', Ed. G. Jaouen, Wiley-VCH, 2006, pp. 1.

[40] B. Rosenberg, L. Vancamp, J. E. Trosko, V. H. Mansour, Nature 1969, 222, 385.

[41] B. Rosenberg, L. VanCamp, Cancer Res. 1970, 30, 1799.

[42] B. Rosenberg, L. Vancamp, T. Krigas, $\mathrm{Na}$ ture 1965, 205, 698.

[43] E. Wong, C. M. Giandomenico, Chem. Rev. 1999, 99, 2451.

[44] B. Lippert, 'Cisplatin: Chemistry and Biochemistry of a Leading Anticancer Drug', John Wiley and Sons, New York, 1999.

[45] C. Descôteaux, J. Provencher-Mandeville, I. Mathieu, V. Perron, S. K. Mandal, E. Asselin, G. Bérubé, Bioorg. Med. Chem. Lett. 2003, 13, 3927.

[46] M. A. Jakupec, M. Galanski, B. K. Keppler, Rev. Physiol. Biochem. Pharmacol. 2003, 146,1 .
[47] C. R. Culy, D. Clemett, L. R. Wiseman, Drugs 2000, 60, 895.

[48] E. von Angerer, in 'Metal Complexes in Cancer Chemotherapy', Ed. B. K. Keppler, VCH, Weinheim, 1993, pp. 73

[49] C. Chesne, G. Leclercq, P. Pointeau, H. Patin, Eur. J. Med. Chem. 1986, 21, 321.

[50] R. Gust, H. Schönenberger, U. Klement K. J. Range, Arch. Pharm. 1993, 326, 967.

[51] J. Karl, R. Gust, T. Spruss, M. R. Schneider, H. Schönenberger, J. Engel, K. H. Wrobel, F. Lux, S. Trebert Haeberlin, $J$ Med. Chem. 1988, 31, 72.

[52] O. Gandolfi, J. Blum, F. MandelbaumShavit, Inorg. Chim. Acta 1984, 91, 257.

[53] G. Grenier, G. Bérubé, C. Gicquaud, Chem. Pharm. Bull. 1998, 46, 1480 .

[54] S. Top, E. B. Kaloun, A. Vessières, G. Leclercq, I. Laïos, M. Ourevitch, C. Deuschel, M. J. McGlinchey, G. Jaouen, ChemBioChem 2003, 4, 754

[55] J. Altman, T. Castrillo, W. Beck, G. Bernhardt, H. Schönenberger, Inorg. Chem. 1991, 30, 4085

[56] A. Jackson, J. Davis, R. J. Pither, A. Rodger, M. J. Hannon, Inorg. Chem. 2001, 40 3964.

[57] 'The Organometallic Chemistry of the Transition Elements', Ed. R. H. Crabtree 4th Edition, J. Wiley and Sons, Hoboken, New Jersey, 2005.

[58] E. I. Edwards, R. Epton, G. Marr, J. Orga nomet. Chem. 1979, 168, 259.

[59] E. I. Edwards, R. Epton, G. Marr, J. Organomet. Chem. 1976, 122, C49.

[60] E. I. Edwards, R. Epton, G. Marr, J. Organomet. Chem. 1975, 85, C23.

[61] A. N. Nesmeyanov, L. G. Bogomolova, V. Viltchevskaya, N. Palitsyne, I. Andrianova, O. Belozerova, USA Patent, 119,356, 1971.

[62] C. Biot, G. Glorian, L. A. Maciejewski, J. S. Brocard, J. Med. Chem. 1997, 40, 3715.

[63] http://www.sanofi-aventis.com/rd/ portfolio/p_rd_portfolio_medecine_interne.asp.

[64] P. Köpf-Meyer, H. Köpf, E. W. Neuse, $J$ Cancer Res. Clin. Oncol. 1984, 108, 336.

[65] E. W. Neuse, F. Kanzawa, Appl. Organomet. Chem. 1990, 4, 19.

[66] D. Osella, M. Ferrali, P. Zanello, F. Laschi, M. Fontani, C. Nervi, G. Cavigiolio, Inorg. Chim. Acta 2000, 306, 42

[67] G. Tabbi, C. Cassino, G. Cavigiolio, D. Colangelo, A. Ghiglia, I. Viano, D. Osella, J. Med. Chem. 2002, 45, 5786.

[68] H. Tamura, M. Miwa, Chem. Lett. 1997, 1177.

[69] S. Top, B. Dauer, J. Vaissermann, G. Jaouen, J. Organomet. Chem. 1997, 541, 355.

[70] S. Top, J. Tang, A. Vessières, D. Carrez, C. Provot, G. Jaouen, Chem. Commun. 1996 , 955.

[71] G. Jaouen, S. Top, A. Vessières, G. Leclercq, J. Quivy, L. Jin, A. Croisy, C. R. Acad. Sci. Paris 2000, Série IIc, 89.
[72] S. Top, A. Vessières, C. Cabestaing, I. Laios, G. Leclercq, C. Provot, G. Jaouen, $J$. Organomet. Chem. 2001, 637, 500.

[73] S. Top, A. Vessières, G. Leclercq, J. Quivy, J. Tang, J. Vaissermann, M. Huché, G. Jaouen, Chem. Eur. J. 2003, 9, 5223.

[74] G. Jaouen, S. Top, A. Vessières, in 'Bioorganometallics', Ed. G. Jaouen, WileyVCH, Weinheim, 2005, pp. 65.

[75] A. Vessières, D. Spera, S. Top, B. Misterkiewicz, J. M. Heldt, E. A. Hillard, M. Huché, M. A. Plamont, E. Napolitano, R. Fiaschi, G. Jaouen, ChemMedChem 2006 $1,1275$.

[76] A. Vessières, S. Top, P. Pigeon, E. A. Hillard, L. Boubeker, D. Spera, G. Jaouen, $J$. Med. Chem. 2005, 48, 3937.

[77] E. A. Hillard, A. Vessières, F. Le Bideau, D. Plazuk, D. Spera, M. Huché, G. Jaouen, ChemMedChem 2006, 1, 551.

[78] E. A. Hillard, P. Pigeon, A. Vessières, C Amatore, G. Jaouen, Dalton Trans. 2007, doi: 10.1039/b705030e.

[79] F. Zhang, P. W. Fan, X. Liu, L. Shen, R B. van Breeman, J. L. Bolton, Chem. Res. Toxicol. 2000, 13, 53.

[80] G. Jaouen, S. Top, A. Vessières, P. Pigeon, G. Leclercq, I. Laïos, Chem. Commun. 2001, 383

[81] P. Pigeon, S. Top, A. Vessières, M. Huché, E. A. Hillard, E. Salomon, G. Jaouen, $J$. Med. Chem. 2005, 48, 2814.

[82] G. Jaouen, S. Top, A. Vessières, G. Leclercq, M. J. McGlinchey, Curr. Med. Chem. 2004, 11, 2505.

[83] A. Vessières, S. Top, W. Beck, E. A. Hillard, G. Jaouen, Dalton Trans. 2006, 4, 529.

[84] E. A. Hillard, A. Vessières, S. Top, P. Pigeon, K. Kowalski, M. Huché, G. Jaouen, J. Organomet. Chem. 2007, 692, 1315.

[85] E. A. Hillard, A. Vessières, L. Thouin, G. Jaouen, C. Amatore, Angew. Chem., Int. Ed. 2006, $45,285$.

[86] P. W. Fan, F. Zhang, J. L. Bolton, Chem. Res. Toxicol. 2000, 13, 45.

[87] A. Nguyen, V. Marsaud, C. Bouclier, S. Top, A. Vessières, P. Pigeon, R. Gref, P. Legrand, G. Jaouen, J.-M. Renoir, Int. J. Pharm. 2007, doi: 10.1016.Jpharm.2007.06.033.

[88] A. Nguyen, S. Top, A. Vessières, P. Pigeon, M. Huché, E. A. Hillard, G. Jaouen, J. Organomet. Chem. 2007, 692, 1219.

[89] K. S. Kraft, P. C. Ruenitz, M. G. Bartlett, $J$. Med. Chem. 1999, 42, 3126.

[90] V. C. Jordan, R. R. Bain, R. R. Brown, B. Gosden, M. A. Santos, Cancer Res. 1983 , 43, 1446.

[91] Q. Qu, H. Zheng, J. Dahllund, A. Laine, N. Cockcroft, Z. Peng, M. Koskinen, K. Hemminki, L. Kangas, K. Vaananen, P. Harkonen, Endocrinology 2000, 141, 809. 